\title{
Prevalence and Antibiotic Resistance of Staphylococcus aureus Isolated From Raw Milk and Dairy Products Collected From Alexandria, Egypt
}

\author{
Sahar G. Abd El-Halem(1), Attia, I.A.(2), El-Dera, H.B.(3) \& El-Seedy, A.S.(4)
}

(1) Alexandria Police Hospital, Ministry of Interior, Alexandria,k Egypt.

(2) Dairy Science and Technology Dept., Fac. of Agric., El-Shatby, 21545, Univ. of Alexandria, Egypt.

(3) Nutrition Dept., High Institute of Public Health, Univ., of Alexandria, Egypt

(4) Laboratory of Cellular and Molecular Genetics, Genetics Dept., Fac. of Agric., El-Shatby, 21545, Univ. of Alexandria, Egypt

Received: 17 September, 2019

Revised: 2 December, 2019

Accepted: 12 December, 2019

\begin{abstract}
The aim of the present study was to determine the prevalence and antibiotic susceptibility of Staphylococcus aureus (S. aureus) isolated from raw milk and some dairy products collected from shops, grocery stores, street vendors at different markets in Alexandria, Egypt and identification of the genes responsible for resistance to some important antibiotics using polymerase chain reaction (PCR) technique. The results of the raw milk and dairy products examined, $22.5 \%$ of the samples were positive for S. aureus. It was isolated from $29 \%$ of raw milk samples, $12.5 \%$ of Kariesh cheese samples, $55 \%$ of White cheese samples, $10 \%$ of Ras cheese samples, $5.7 \%$ of yoghurt samples and $24.3 \%$ of cream samples. Antimicrobial susceptibility test revealed that all the isolates were susceptible to ciprofloxacin, co-trimoxazole, linezolid, rifampin and vancomycin. Resistance to penicillin $\mathrm{G}$, tetracycline, cefoxitin, chloramphenicol, erythromycin and gentamycin were detected in $91.4 \%, 65.4 \%, 42 \%, 13.6 \%, 12.3 \%$ and $9.9 \%$ of the isolates, respectively. The mecA resistance gene was identified in $91.2 \%$ of cefoxitin resistant $\mathrm{S}$. aureus isolates, aacA-D was detected in $87.5 \%$ gentamycin resistant isolates and ermC gene was detected in $100 \%$ of S. aureus isolates showed macrolides resistance whereas ermA could not detected in any of them. The overall prevalence of methicillin resistant S. aureus (MRSA) in the tested raw milk and dairy product samples was $8.6 \%$. The highest methicillin resistant S. aureus prevalence was reported in white cheese samples of $22.5 \%$ followed by raw milk, Ras cheese, cream, yoghurt and Kariesh cheese with prevalence of $11 \%, 7.5 \% 7.14 \% 2.9 \%$ and $2.5 \%$, respectively.
\end{abstract}

Key words: Staphylococcus aureus, dairy products, prevalence, antibiotic resistance.

\section{INTRODUCTION}

Staphylococcus aureus is an important pathogen for both human and animals (Fetsch \& Johler, 2018). It is normal inhabitant of the skin, nasal cavity and mucus membranes of humans, and may colonize the skin and upper respiratory tract of other mammals. It can cause various pyogenic and systemic infections, acute and chronic infections, and toxin-mediated syndromes disease as toxic shock syndrome, food poisoning and staphylococcal scalded skin syndrome (Hu et al., 2018). S. aureus is one of the main causes of bovine mastitis; it is responsible for approximately $30 \%$ to $40 \%$ of all mastitis cases which can easily contaminate raw milk (Gwida \& El-Gohary, 2013).

$S$. aureus is a major cause of food poisinging worldwide and one of the main pathogen associated with the consumption of raw milk and dairy products. S. aureus can contaminate milk through infected producing animals or from human source during milking and handling through hand or arm lesions caused by $S$. aureus or by coughing and sneezing, during respiratory infections (El-Malt et al., 2013).

The misuse and overuse of antimicrobial agents in veterinary practice resulted in the development of resistant bacteria which may spread to humans through the food supply (Aydin et al., 2011). S. aureus is capable of acquiring antibiotic resistance determinants and therefore, often show resistance to multiple classes of antibiotics (Papadopoulos et al., 2018). Staphylococcus developed resistance to a wide range of antimicrobial drugs, since the introduction of penicillin in 1942 until now (Akpaka et al., 2017). S. aureus strains have been reported for resistance against various antibiotic classes such as beta-lactams, tetracyclines, aminoglycosides, fluoroquinolones, lincosamides, macrolides and streptogramins that are widely used in veterinary medicine (Kumar et al., 2010). 
There is a rising awareness about the antibiotic resistant bacteria and their effect on public health, thus studying antibiotic resistance in food animal products is essential for detecting changing patterns of resistance, implementing control measures on the use of antibiotics to eliminate the spread of antibiotic resistant bacteria. The aim of this study was to determine the prevalence and antibiotic resistance of $S$. aureus isolated from raw milk, cheese, yoghurt and cream samples collected from dairy shops, grocery stores, street vendors at different markets in Alexandria, Egypt and identification of the genes responsible for resistance to some important antibiotics.

\section{MATERIALS AND METHODS}

\section{Materials}

A total of 360 samples consist of 100 raw milk (cow and buffalo), 120 cheese (40 of each Kariesh cheese, white cheese and Ras cheese), 70 yoghurt samples and 70 cream samples were collected during the period from January 2016 to March 2017 at consumer level from dairy shops, grocery stores, street vendors at different markets in Alexandria governorate, Egypt. The samples were collected and transported in ice box to the laboratory.

\section{Methods}

Twenty five $\mathrm{ml}$ of raw milk or twenty five gram of the other dairy products were added to $225 \mathrm{ml}$ of the recommended diluent according to ISO 6887-5: 2010 method. Saline peptone water was used for raw milk, sodium citrate diluent was used for Kariesh cheese, white cheese, and Ras cheese samples, di-potassium hydrogen phosphate diluent was used for yoghurt samples. For cream samples, $25 \mathrm{~g}$ of cream was added to $225 \mathrm{ml}$ of saline peptone water and warmed to $45^{\circ} \mathrm{C}$ until the sample was completely melted. Saline peptone water was used for preparing decimal dilutions for all the samples.

\section{Isolation and identification of $S$. aureus}

Isolation of $S$. aureus was carried according to ISO 6888-1:1999 by plating $0.1 \mathrm{ml}$ of each of the initial suspension on the surface of Baird-Parker agar (Lab M, UK) supplemented with egg yolk tellurite emulsion $(50 \mathrm{ml} / \mathrm{L})$, and incubated at $37^{\circ} \mathrm{C}$ for $48 \mathrm{hr}$. Typical coagulase positive colonies are black or grey, shining and convex and surrounded by a clear zone. Two isolates with typical $S$. aureus morphology per sample were selected and confirmed by biochemical tests ( rabbit plasma coagulation, identified as Gram-positive cocci, catalase positive, oxidase negative, DNase positive, negative for indol production, can ferment lactose, sucrose, glucose and mannitol.)

\section{Antibiotic susceptibility test}

The antimicrobial susceptibility phenotypes of $S$. aureus isolates were determined using KirbyBauer disk diffusion assay according to the standards and interpretive criteria described by Clinical and Laboratory Standards Institute (CLSI,2012CLSI, 2016). Only one confirmed isolate per sample was tested. The results were recorded based on CLSI guidelines. S. aureus isolates were tested against cefoxitin (FOX,30 $\mu \mathrm{g}$ ), chloramphenicol $(\mathrm{C}, 30 \mu \mathrm{g})$, ciprofloxacin (CIP, $5 \mu \mathrm{g})$, clindamycin (DA, $2 \mu \mathrm{g}$ ) , co-trimoxazole (SXT, 1.25/23.75 $\mu \mathrm{g}$ ) , erythromycin $(\mathrm{E}, 15 \mu \mathrm{g})$, gentamicin $(\mathrm{CN}, 10 \mu \mathrm{g})$ , linezolid (LZ, $30 \mu \mathrm{g})$, penicillin $\mathrm{G}(\mathrm{P}, 10 \mathrm{U})$, rifampicin(RA, $5 \mu \mathrm{g})$, tetracycline (TE, $30 \mu \mathrm{g}$ ) and vancomycin (VA, $30 \mu \mathrm{g})$.

Table 1: Primers used for antibiotic resistance genes amplification

\begin{tabular}{|c|c|c|c|c|}
\hline Gene & Primer name & Primer sequence & Size (bp) & $\begin{array}{l}\text { Annealing } \\
\text { Temp. }{ }^{\circ} \mathrm{C}\end{array}$ \\
\hline \multirow{2}{*}{$\operatorname{mecA}$} & mecA F & AAAATCGATGGTAAAGGTTGGC & \multirow{2}{*}{532} & \multirow{2}{*}{55} \\
\hline & mecA R & AGTTCTGCAGTACCGGATTTGC & & \\
\hline \multirow{2}{*}{$\operatorname{erm} \mathbf{A}$} & ermA F & AAGCGGTAAACCCCTCTGA & \multirow{2}{*}{190} & \multirow{2}{*}{55} \\
\hline & ermA R & TTCGCAAATCCCTTCTCAAC & & \\
\hline \multirow{2}{*}{ erm C } & erm C F & AATCGTCAATTCCTGCATGT & \multirow{2}{*}{299} & \multirow{2}{*}{55} \\
\hline & erm C R & TAATCGTGGAATACGGGTTTG & & \\
\hline \multirow{2}{*}{$\operatorname{aacA}-\mathrm{D}$} & $a a c \mathrm{~A}-\mathrm{D} \mathrm{F}$ & TAATCCAAGAGCAATAAGGGC & \multirow{2}{*}{227} & \multirow{2}{*}{55} \\
\hline & aacA-D R & GCCACACTATCATAACCACTA & & \\
\hline
\end{tabular}




\section{Detection of antimicrobial resistance genes}

The presence of genes associated with resistance to methicillin (methicillin resistance mecA gene), erythromycin and clindamycin (erythromycin ribosome methylases erm $\mathrm{A}$, erm $\mathrm{C}$ genes), gentamicin (aminoglycoside acetyltransferases aacA-D gene) were detected by polymerase chain reaction (PCR) (Techne thermal cycler PHC-3, Cambridgem, UK) and the set of primers (Kumar et al., 2010) used for each gene is shown in Table (1). Bacterial DNA was extracted using QIAamp ${ }^{\circledR}$ DNA Mini Kit (QIAgen, Germany) according to the manufacturer's instructions and used as DNA template for (PCR).

\section{RESULTS AND DISCUSSION}

\section{Prevalence of $S$. aureus}

Table (2) represents the prevalence of $S$. aureus in raw milk and some dairy products collected from Alexandria. Out of the 360 examined samples, $22.5 \%$ of samples were positive for $S$. aureus. White cheese samples had the highest $S$. aureus prevalence of $55 \%$ followed by the raw milk, cream, Kariesh cheese and Ras cheese samples with prevalence of $29 \%, 24.3 \%, 12.5 \%$ and $10 \%$, respectively. Whereas yoghurt samples had the lowest $S$. aureus prevalence of $5.7 \%$.

Agban \& Ahmed (2013) detected S. aureus in $28 \%$ of raw milk samples collected from Assiut governorate's rural areas. Elbagory et al.(2015) and Fadel \& Ismail (2015) reported higher prevalence of $60 \%$ and $40 \%$ for $S$. aureus in raw milk samples collected from El-Gharbia, and Ismailia governorates, respectively. Whereas, lower prevalence of $16.3 \%$ were reported by Mansour et al.(2017) for $S$. aureus in raw milk samples from Cairo, Giza, Kafr El-Sheikh governorates.

For Kariesh cheese, similar results were found by Salem et al. (2016) who reported a prevalence of $12.6 \%$ for samples collected from Alexandria. However, higher prevalence was reported by Agben \& Ahmed (2013), Elbagory et al. (2015), Fadel \& Ismail (2015) who reported a prevalence of 37\%, $52.5 \%$ and $63.3 \%$ for Kariesh cheese samples collected from Assiut, El-Gharbia, and Ismailia governorates, respectively.

Atef et al. (2017) reported a similar prevalence of $5 \%$ for $S$. aureus in yoghurt samples collected from both El-Minya and Alexandria governorates.
On the other hand, higher prevalence of $42 \%$ were reported by El-Ansary et al. (2014) in yoghurt samples collected from El-Behera governorate. Also, Ahmed et al. (2014) reported a prevalence of 86.4 $\%$ in yoghurt samples collected from Cairo, Giza and Monfiya governorates. Whereas Sadek et al. (2014) could not detect $S$. aureus from yoghurt samples in Assiut governorate.

In contrary, higher prevalence of $75.5 \%$ and $31.4 \%$ for $S$. aureus were reported by Nazem et al.(2015) and Meshref (2013) for cream samples collected from Alexandria governorate and BeniSuef city, respectively.

The relatively high prevalence of $S$. aureus in white cheese compared to the other products may be due to the use of unsuitable heat treated milk in the manufacturing of cheese and favorable conditions for bacterial growth during cheese making.

Table 2: Prevalence of $S$. aureus in raw milk and some dairy products collected from Alexandria governorate

\begin{tabular}{llll}
\hline \multirow{2}{*}{ Products } & \multirow{2}{*}{$\begin{array}{c}\text { No of examined } \\
\text { samples }\end{array}$} & \multicolumn{2}{c}{ positive samples } \\
\cline { 3 - 4 } & 100 & 29 & No \\
\hline Raw milk & 100 & 5 & 12.5 \\
Kariesh cheese & 40 & 22 & 55.0 \\
White cheese & 40 & 4 & 10 \\
Ras cheese & 40 & 4 & 5.7 \\
Yoghurt & 70 & 17 & 24.3 \\
Cream & 70 & 81 & 22.5 \\
Overall & 360 & &
\end{tabular}

\section{Antibiotic susceptibility of $\boldsymbol{S}$. aureus isolates}

The WHO developed a list of critically important antimicrobials to rank antimicrobials according to their importance in human medicine. It was created for use in developing risk management strategies to know which types of antimicrobials used in animals represent potentially higher risks to human populations. The list categorizes antimicrobials into three groups: critically important, highly important, and important (Collignon et al., 2016).

Antibiotic susceptibility test of the $S$. aureus isolates revealed that all the isolates were susceptible to ciprofloxacin, co-trimoxazole, linezolid, rifampin and vancomycin. Thirty four $(42 \%)$ of the isolates were resistant to cefoxitin and considered to be suspected methicillin resistant $S$. aureus. Resistance to penicillin G, tetracycline, cefoxitin, 
chloramphenicol, erythromycin and gentamycin were detected in $92.6 \%, 65.4 \%, 42 \%, 13.6 \%, 12.3$ $\%$ and $9.9 \%$ of the isolates, respectively. Antibiotic resistance of $S$. aureus isolates are presented in Table (3)

Similar antibiotic resistance phenotypes were also reported in Egypt for $S$. aureus isolates from raw milk samples but with different percentages. Sadek et al. (2014) reported that $S$. aureus isolates from raw milk samples collected from Assiut governorate were sensitive to erythromycin, co-trimoxazole and ciprofloxacin and $7.6 \%$ and $17.4 \%$ of the isolates were resistance to tetracycline and gentamycin, respectively. Elmonier et al.(2018) found that $90.1 \%, 77.3 \%, 72.7 \%, 22.7 \%$ and $9.1 \%$ of $S$. aureus isolates from raw milk samples collected from Kafr El-Sheikh governorate were resistance to tetracycline, erythromycin, chloramphenicol, gentamicin, and cefoxitin, respectively.

Many different results for $S$. aureus resistance phenotypes from raw milk and dairy products have been reported all over the world. In Ethiopia, $92.2 \%$ and $66.7 \%$ of $S$. aureus isolates from milk samples were resistance to penicillin $G$ and tetracycline, respectively (Mekuria et al., 2013). In Iran, S. aureus isolates from raw cow milk, raw sheep milk, traditional cheese and kashk samples (prolonged boiled yoghurt) were sensitive to co- trimoxazole and ciprofloxacin whereas, $56.1 \%$, $11.3 \%, 7.9 \%$ of the isolates were resistant to tetracycline, clindamycin and erythromycin, respectively (Jamali et al., 2015). Moreover, S. aureus isolates from milk samples collected from small scale dairy farms in Penang, Malaysia were sensitive to chloramphenicol, ciprofloxacin and gentamycin, and $50 \%, 10 \%$ and $8.3 \%$ were resistance to tetracycline, clindamycin and erythromycin, respectively. Also, isolates showed lower resistance of $23.3 \%$ and $15.0 \%$ to penicillin $\mathrm{G}$ and cefoxitin, respectively (Shamila-Syuhada et al., 2016). In north-western Greece, $99.3 \%$ and $28.2 \%$ of the 212 S. aureus isolates from 367 samples of bulk milk tank, dairy products, nasal swabs, and swabs from dairy plant equipment surfaces, collected from two dairy plants and 24 dairy farms, were resistant to penicillin and tetracycline, respectively; and $3.8 \%$ were suspected MRSA according to their antimicrobial resistance to oxacillin. Prevalence of MRSA was reported to be $10 \%, 2.4 \%, 6.5 \%$ and $7.3 \%$ in bovine milk, farm workers, plant workers, and in plant equipment, respectively; and no MRSA was detected in any dairy product tested( Papadopoulos et al., 2018)

Thirteen different resistance patterns were observed (Table 4). Resistance to penicillin G (P) alone was the highest reported pattern for resistance

Table 3: Antibiotic resistance of $S$. aureus isolates from raw milk and dairy products collected from Alexandria governorate

\begin{tabular}{|c|c|c|c|c|c|c|c|c|c|c|c|c|c|c|}
\hline \multirow{3}{*}{ Antibiotic } & \multicolumn{2}{|c|}{ Raw milk } & \multicolumn{2}{|c|}{$\begin{array}{l}\text { Kariesh } \\
\text { cheese }\end{array}$} & \multicolumn{2}{|c|}{$\begin{array}{l}\text { white } \\
\text { cheese }\end{array}$} & \multicolumn{2}{|c|}{ Ras cheese } & \multicolumn{2}{|c|}{ Yoghurt } & \multicolumn{2}{|c|}{ Cream } & \multicolumn{2}{|c|}{ Total isolates } \\
\hline & \multicolumn{2}{|c|}{$\mathrm{N}^{*}=29$} & \multicolumn{2}{|c|}{$\mathrm{N}=5$} & \multicolumn{2}{|c|}{$\mathrm{N}=22$} & \multicolumn{2}{|c|}{$\mathrm{N}=4$} & \multicolumn{2}{|c|}{$\mathrm{N}=4$} & \multicolumn{2}{|c|}{$\mathrm{N}=17$} & \multicolumn{2}{|c|}{$\mathrm{N}=81$} \\
\hline & No & $\%$ & No & $\%$ & No & $\%$ & No & $\%$ & No & $\%$ & No & $\%$ & No & $\%$ \\
\hline Cefoxitin & 12 & 41.4 & 1 & 20.0 & 9 & 40.9 & 3 & 75.0 & 2 & 50.0 & 7 & 41.8 & 34 & 42.0 \\
\hline Chloramphenicol & 4 & 13.8 & 0 & 0 & 4 & 18.2 & 1 & 25.0 & 1 & 25.0 & 1 & 5.9 & 11 & 13.6 \\
\hline Ciprofloxacin & 0 & 0 & 0 & 0 & 0 & 0 & 0 & 0 & 0 & 0 & 0 & 0 & 0 & 0 \\
\hline Clindamycin & 6 & 20.7 & 0 & 0 & 2 & 9.1 & 2 & 50.0 & 0 & 0 & 0 & 0 & 10 & 12.3 \\
\hline Co-trimoxazole & 0 & 0 & 0 & 0 & 0 & 0 & 0 & 0 & 0 & 0 & 0 & 0 & 0 & 0 \\
\hline Erythromycin & 6 & 20.7 & 0 & 0 & 2 & 9.1 & 2 & 50.0 & 0 & 0 & 0 & 0 & 10 & 12.3 \\
\hline Gentamycin & 2 & 6.9 & 1 & 20.0 & 2 & 9.1 & 2 & 50.0 & 0 & 0 & 1 & 5.9 & 8 & 9.9 \\
\hline Linezolid & 0 & 0 & 0 & 0 & 0 & 0 & 0 & 0 & 0 & 0 & 0 & 0 & 0 & 0 \\
\hline Penicillin G & 25 & 86.2 & 5 & 100 & 21 & 95.5 & 4 & 100 & 4 & 100 & 16 & 94.1 & 75 & 92.6 \\
\hline Rifampin & 0 & 0 & 0 & 0 & 0 & 0 & 0 & 0 & 0 & 0 & 0 & 0 & 0 & 0 \\
\hline Tetracycline & 18 & 62.1 & 4 & 80.0 & 15 & 68.2 & 1 & 25.0 & 3 & 75.0 & 12 & 70.6 & 53 & 65.4 \\
\hline Vancomycin & 0 & 0 & 0 & 0 & 0 & 0 & 0 & 0 & 0 & 0 & 0 & 0 & 0 & 0 \\
\hline
\end{tabular}

$* \mathrm{~N}$ : number of isolates 
to one antibiotic which was observed in 15 isolates. Resistance to penicillin $\mathrm{G}$ and tetracycline (P-TE) was the highest reported frequency in 24 isolates. Whereas resistance to penicillin, tetracycline and cefoxitin (P-TE-FOX) was the highest multi drug resistance (MDR) pattern which was reported in 10 S. aureus isolates Table (4).

Table (5) shows the distribution of $S$. aureus isolates according to their resistance to one, two or more antibiotics. It can be noted from the Table that $93.8 \%$ of the isolates were resistant to at least one antibiotic. Sixteen out of the 81 isolates $(19.8 \%)$ were resistant to one antibiotic, Twenty eight out of the 81 isolates $(34.86 \%)$ were resistant to two antibiotics, Thirty two out of the 81 isolates (39.5\%) showed MDR. In accordance to these results, $34.8 \%$ of $S$. aureus isolates from raw milk samples sold in some Assiut city markets showed MDR (Sadek et al., 2014). Samaha et al. (2012) reported that $95.5 \%$ of $S$. aureus isolates from raw milk samples collected from Kafr El-Sheikh governorate showed multidrug resistant.

\section{Antibiotic resistance genes}

The 34 phenotypically suspected MRSA isolates ( $S$. aureus showed resistance to cefoxitin) were confirmed by detecting the presence of mecA gene using PCR. Table (6) showed that 31 out of the 34 cefoxitin resistant $S$. aureus isolates were found to harbor the mecA gene, whereas it could not be detected in 3 isolates, one isolate from the raw milk samples and 2 isolates from cream samples. It can be noted from the Table that the highest MRSA prevalence was reported in white cheese

Table 4: Frequency of antibiotic resistance patterns of $S$. aureus isolates

\begin{tabular}{llllllll}
\hline Antibiotic resistance pattern & $\begin{array}{l}\text { Raw } \\
\text { milk }\end{array}$ & $\begin{array}{c}\text { Kariesh } \\
\text { cheese }\end{array}$ & $\begin{array}{c}\text { White } \\
\text { cheese }\end{array}$ & $\begin{array}{c}\text { Ras } \\
\text { cheese }\end{array}$ & Yoghurt & Cream & Total \\
\hline TE & 1 & - & - & - & - & - & 1 \\
P & 5 & 1 & 6 & 1 & - & 2 & 15 \\
P-TE & 8 & 3 & 5 & - & 2 & 6 & 24 \\
P-FOX & 1 & - & - & - & 1 & 2 & 4 \\
P-TE-FOX & 2 & - & 4 & - & - & 4 & 10 \\
P-TE-C & - & - & 1 & - & - & 1 & 2 \\
P-TE-FOX-C & 1 & - & 2 & 1 & 1 & - & 5 \\
P-TE-FOX-CN & 2 & 1 & 1 & - & - & 1 & 5 \\
P-FOX-E/DA & 2 & - & - & - & - & - & 2 \\
P-FOX-E/DA-CN & - & - & - & 2 & - & - & 2 \\
P-TE-FOX-E/DA & 1 & - & - & - & - & - & 1 \\
P-TE-FOX-E/DA-C & 3 & - & 1 & - & - & - & 4 \\
P-TE-FOX-E/DA-CN & - & - & 1 & - & - & - & 1 \\
\hline
\end{tabular}

C: Chloramphenicol CN: Gentamicin DA: Clindamycin E: Erythromycin FOX: Cefoxitin P: Penicillin TE: Tetracycline

Table 5: Distribution of $S$. aureus isolates according to their resistance to one, two or more antibiotics

\begin{tabular}{|c|c|c|c|c|c|c|c|c|c|}
\hline \multirow[t]{2}{*}{ Product } & \multirow{2}{*}{$\begin{array}{l}\text { No of } \\
\text { isolates }\end{array}$} & \multicolumn{2}{|c|}{$\begin{array}{l}\text { Resistance to one } \\
\text { antibiotic }\end{array}$} & \multicolumn{2}{|c|}{$\begin{array}{l}\text { Resistance to two } \\
\text { antibiotics }\end{array}$} & \multicolumn{2}{|c|}{$\begin{array}{l}\text { Multidrug } \\
\text { Resistance }\end{array}$} & \multicolumn{2}{|c|}{ Overall resistance } \\
\hline & & No & $\%$ & No & $\%$ & No & $\%$ & No & $\%$ \\
\hline Raw milk & 29 & 6 & 20.7 & 9 & 31.0 & 11 & 37.9 & 26 & 89.7 \\
\hline Kariesh cheese & 5 & 1 & 20.0 & 3 & 60.0 & 1 & 20.0 & 5 & 100 \\
\hline white cheese & 22 & 6 & 27.3 & 5 & 22.7 & 10 & 45.5 & 21 & 95.5 \\
\hline Ras cheese & 4 & 1 & 25.0 & 0 & 0.0 & 3 & 75.0 & 4 & 100 \\
\hline Yoghurt & 4 & 0 & 0.0 & 3 & 75.0 & 1 & 25.0 & 4 & 100 \\
\hline Cream & 17 & 2 & 11.8 & 8 & 47.1 & 6 & 35.3 & 16 & 94.1 \\
\hline Total & 81 & 16 & 19.8 & 28 & 34.6 & 32 & 39.5 & 76 & 93.8 \\
\hline
\end{tabular}


samples of $22.5 \%$ followed by raw milk, Ras cheese, cream, yoghurt and Kariesh cheese samples with prevalence of $11 \%, 7.5 \% 7.14 \% 2.9 \%$ and $2.5 \%$, respectively, and the overall prevalence of MRSA in the tested raw milk and dairy product samples was $8.6 \%$.

Erythromycin resistant $S$. aureus isolates were tested for the presence of macrolide resistance genes (erm $\mathrm{A}$ and $\mathrm{erm} \mathrm{C}$ ). erm $\mathrm{C}$ gene was detected in all the $10 \mathrm{~S}$. aureus isolates showed macrolides resistance whereas ermA could not detected in any of them. The eight $S$. aureus isolates which showed resistance to gentamycin were tested for the presence of aacA-D gene and seven of them were found to harbor the target gene.

In accordance to these results, a prevalence of $9.1 \%$ for MRSA isolates identified by resistance to cefoxitin and PCR detection of mecA gene was reported for milk samples collected from Kafr El-Sheikh, Egypt (Elmonier et al., 2018). Al-Ashmawy et al. (2014) found that all S. aureus isolates from milk and dairy products collected from Mansoura city, Egypt, were genetically verified as MRSA, harboring mecA gene. MRSA prevalence reported to be $75 \%, 65 \%, 40 \%, 50 \%$ and $35 \%$ in raw milk, Damietta cheese, Kariesh cheese, ice cream and yoghurt samples, respectively, and 53\% of all milk and dairy products tested. Also, Fadel \& Ismail (2015) reported prevalence of $33.3 \%$, $20 \%, 13.3 \%, 40 \%, 13.3 \%, 33.3 \%$ and $13.3 \%$ for MRSA isolates with positive mecA gene for goat milk, sheep milk, buffalo milk, yoghurt, ice cream, Kariesh cheese samples and dairy workers swaps, respectively, collected from Ismailia city, Egypt.
Variable prevalence of MRSA in milk and dairy products in different countries has been reported. In central Italy, MRSA isolates which were positive to both mecA and $b l a_{\mathrm{Z}}$ genes reported to be $1.3 \%$ of all the $S$. aureus isolates from different milk and dairy products. MRSA was found in pasta filata cheese and ovine bulk tank milk from two different farms (Carfora et al., 2015). In Balikesir, Turkey, only three samples ( 2 from cow milk bulk tank and one from Tulum cheese) of 175 milk and dairy products tested were MRSA phenotypically being resistant to both oxacillin and cefoxitin, and only one was confirmed as MRSA carrying the mecA gene (Ektik et al., 2018). In Faisalabad, Pakistan the prevalence of confirmed MRSA isolates by molecular methods targeting mecA was $34 \%$ in overall bovine milk samples (Aqib et al., 2017). In Jordon, the prevalence of MRSA isolates confirmed by detecting mecA gene in bulk milk samples from cattle, sheep and goat milk was $20 \% 39.1 \%$ and $11.9 \%$, respectively ( Obaidat et al., 2018).

\section{CONCLUSION}

A considerable portion of the examined samples was found to be contaminated with $S$. aureus which may constitute public health hazard and may lead to food poisoning. Moreover, the detection of antibiotic resistant $S$. aureus and the associated resistant genes in the examined samples indicates that raw milk, Kariesh cheese, white cheese, Ras cheese, yoghurt and cream may possess a public health hazard as there is strong evidence that human consumption of food contains antibiotic resistant bacteria resulted in acquisition of antibiotic resistant infections.

Table 6: Prevalence of confirmed methicillin-resistant $S$. aureus isolates in raw milk and dairy products collected from Alexandria governorate

\begin{tabular}{|c|c|c|c|c|c|}
\hline \multirow[t]{2}{*}{ Product } & \multirow[t]{2}{*}{ No. of examined samples } & \multicolumn{2}{|c|}{$\begin{array}{c}\text { Suspected } \\
\text { MRSA isolates * }\end{array}$} & \multicolumn{2}{|c|}{$\begin{array}{c}\text { Confirmed } \\
\text { MRSA isolates } *\end{array}$} \\
\hline & & No & $\%$ & No & $\%$ \\
\hline Raw milk & 100 & 12 & 12 & 11 & 11 \\
\hline Kariesh cheese & 40 & 1 & 2.5 & 1 & 2.5 \\
\hline white cheese & 40 & 9 & 22.5 & 9 & 22.5 \\
\hline Ras cheese & 40 & 3 & 7.5 & 3 & 7.5 \\
\hline Yoghurt & 70 & 2 & 2.9 & 2 & 2.9 \\
\hline Cream & 70 & 7 & 10 & 5 & 7.14 \\
\hline Total & 360 & 34 & 9.4 & 31 & 8.6 \\
\hline
\end{tabular}

*Suspected MRSA isolates: cefoxitin- resistance isolates

**Confirmed MRSA isolates: mecA gene positive isolates 


\section{REFERENCES}

Agban, M.N. \& Ahmed, A.S. 2013. Detection and identification of $S$. aureus enterotoxins in some milk products and their handlers. Egyptian Journal of Medical Microbiology, 22 :101-111.

Ahmed, L.I., Morgan, S.D., Hafez, R.S. \& AbdelAll, A.A.A. 2014. Hygienic quality of some fermented milk products. International Journal of Diary Science, 9:63-73.

Akpaka, P.E., Roberts, R. \& Monecke, S.2017. Molecular characterization of antimicrobial resistance genes against Staphylococcus aureus isolates from Trinidad and Tobago. Journal of Infection and Public Health, 10: 316-323.

Al-Ashmawy, M.A. \&, Sallam, K.I. 2014. Prevalence, detection of Marker and virulence genes of methicillin -resistant Staphylococcus aureus (MRSA) isolated from milk and dairy products and their antimicrobial susceptibility. Zagazig Veterinary Journal. 42: 31-40.

Aqib, A.I., ljaz, M., Anjum, A.A., Malik, M.A., Mehmood, K. \& Farooqi, S.H.2017. Antibiotic susceptibilities and prevalence of methicillin resistance Staphylococcus aureus (MRSA) isolated from bovine milk in Pakistan. Acta Tropica, 176:168-172.

Atef, N., Ibrahim, M., Sleim, A.A. \& Abdel-Mageed, A.-R.2017. Molecular characterization of pathogenic E. coli and Staphylococcus aureus isolated from some fermented milk products by using PCR. Alexandria Journal of Veterinary Science, 54: 127-134.

Aydin, A., Muratoglu, K., Sudagidan, M., Bostan, K., OkuKlu, B. \& Harsa, S.2011. Prevalence and antibiotic resistance of foodborne Staphylococcus aureus isolates in Turkey. Foodborne Pathogens and Disease, 8(1):63-69.

Carfora, V., Caprioli, A., Marri, N., Sagrafoli, D., Giacinti, G. \& Giangalini, G. 2015. Enterotoxin genes, enterotoxin production, and methicillin resistance in Staphylococcus aureus isolated from milk and dairy products in Central Italy, International Dairy Journal. 42:1215.

Clinical and Laboratory Standards Institute (CLSI). Performance standards for antimicrobial disk susceptibility tests, approved standard. $11^{\text {th }}$ ed. CLSI document M02-A11. Wayne, PA,
USA: Clinical and Laboratory Standards Institute, 2012.

Clinical and Laboratory Standards Institute (CLSI). Performance standards for antimicrobial susceptibility testing. $26^{\text {th }}$ ed. CLSI supplement M100S. Wayne, PA, USA: Clinical and Laboratory Standards Institute, 2016.

Collignon, P.C., Conly, J.M., Antoine, A., McEwen, S.A. \& Aidara-Kane, A. 2016. World Health Organization ranking of antimicrobials according to their importance in human medicine: a critical step for developing risk management strategies to control antimicrobial resistance from food animal production. Clinical Infectious Diseases, 63(8):10871093.

Ektik, N., Gökmen, M. \& Çibik, R. 2018. The prevalence and antibiotic resistance of methicillinresistant Staphylococcus aureus (MRSA) in milk and dairy products in Balikesir, Turkey. Journal of the Hellenic Veterinary Medical Society, 68(4): 613-620.

El-Ansary, M.2014. Assessment of microbiological quality of yoghurt sold in El-Behera governorate. Alexandria Journal of Veterinary Science, 43: 52-57.

Elbagory, A.M., Eman, Sh. E. \& Eman, K.F. 2015. Impact of probiotic strains on growth of some food poisoning bacteria from milk and soft cheese. Nutrition and Food Technology, 1(2).6pp. [Cited 2018 Sep 15]. Available from: https://sciforschenonline.org/journals/ nutrition-food/article-data/NFTOA-1-107/ NFTOA-1-107.pdf

El-Malt, L.M., Abdel Hameed, K.G. \& Mohammed, A.S.2013. Microbiological evaluation of yoghurt products in Qena city, Egypt. Veterinary World, 6:400-404.

Elmonier, W., Bbo-Remela, E.M. \& Sobeih, A.2018. Public health risks of Escherichia coli and Staphylococcus aureus in raw bovine milk sold in informal markets in Egypt. Journal of Infection in Developing Countries, 12:533-541.

Fadel, H.M. \& Ismail, J.2015. Occurrence and zoonotic importance of methicillin-resistant Staphylococcus aureus in raw milk and some dairy products at Ismailia city, Egypt. Zagazig Veterinary Journal, 43:95-104. 
Fetsch, A., Johler S. 2018. Staphylococcus aureus as foodborne pathogens. Currant Clinical Microbiology Reports, 5: 88-96.

Gwida, M.M. \& El-Gohary, F.A.2013. Zoonotic bacterial pathogens isolated from raw milk with special reference to Escherichia coli and Staphylococcus aureus in Dakahlia Governorate, Egypt. Open accesses scientific reports, 2: 705. 4pp. [Cited 2018 Sep 23]. Available from: https://www.omicsonline.org/scientific-reports/ADR-SR-705.pdf

Hu, D.L., Wang, L., Fang, R., Okamura, M. \& Ono, H.K., 2018. In: Fetsch, A., (Ed.) S. aureus. London, UK: Elsevier, pp.13-50.

International Organization for Standardization. ISO 6887-5: 2010, Microbiology of food and animal feeding stuffs-preparation of test samples, initial suspension and decimal dilutions for microbiological examination-Part 5: specific rules for the preparation of milk and milk products. Switzerland: International Organization for Standardization, 2010.

International Organization for Standardization. ISO 6888-1:1999/Am1:2003, Microbiology of food and animal feeding stuffs -Horizontal method for the enumeration of coagulasepositive staphylococci (Staphylococcus aureus and other species) - Part 1: Technique using Baird-Parker agar medium. Switzerland: International Organization for Standardization, 2003.

Jamali, H., Paydar, M., Radmehr, B. \& Ismail, S.2015. Prevalence and antimicrobial resistance of Staphylococcus aureus isolated from raw milk and dairy products. Food Control, 54:383-388.

Kumar, R., Yadav, B.R. \& Singh, R.S. 2010. Genetic determinants of antibiotic resistance in Staphylococcus aureus isolates from milk of mastitic crossbred cattle. Currant Microbiology, 60:379-386.

Mansour, A.S., Wagih, GE-S., Morgan, S.D., Elhariri, M., El-Shabrawy, M.A. \& Abuelnaga, A.S.M. 2017. Detection of Staphylococcus aureus enterotoxigenic strains in bovine raw milk by reversed passive latex agglutination and multiplex polymerase chain reaction. Veterinary World, 10: 843847.

Mekuria, A., Asrat, D., Woldeamanuel, Y. \& Tefer, G.2013. Identification and antimicrobial sus- ceptibility of Staphylococcus aureus isolated from milk samples of dairy cows and nasal swabs of farm workers in selected dairy farms around Addis Ababa, Ethiopia. African Journal of Microbiology Research,7: 3501-3510.

Meshref, A.M.S. 2013. Bacteriological quality and safety of raw cow's milk and fresh cream. Slovenian Veterinary Research, 50: 21-30.

Nazem, A.M., Ahmed, A.A. \& Essam, M.M. 2015. Microbiological value and healthy hazard associated with cream sold in local markets at Alexandria city. Alexandria Journal of Veterinary Science, 47: 209-215.

Obaidat, M.M., Bani Salman, A.E. \& Roess, A.A.2018. High prevalence and antimicrobial resistance of mecA Staphylococcus aureus in dairy cattle, sheep, and goat bulk tank milk in Jordan. Tropical Animal Health Production, 405-412.

Papadopoulos, P., Papadopoulos, T., Angelidis, A.S., Boukouvala, E., Zdragas, A. \& Papa, A. 2018. Prevalence of Staphylococcus aureus and of methicillin-resistant $S$. aureus (MRSA) along the production chain of dairy products in north-western Greece. Food Microbiology, 69:43-50.

Sadek, O.A., Sayed ,S.M., El-Berbawy, S.M., Mansy, M.F. \& Hussien, M.F.2014. Some antibiotic resistant bacteria of public health hazard isolated from raw milk sold in some Assiut city markets. Assiut University Bulletin for Environmental Researches, 17: 97-107.

Salem, H.A., El-Attar, L.A. \& Omran, E.A. 2016. Microbiological assessment of some parameters of Kariesh cheese sold by supermarkets and street vendors in Alexandria, Egypt. Journal of High Institute Public Health, 46 (2):77-85.

Samaha, H.A., Haggag, Y.N., Nossair, M.A. \& Mohammad, H.S.2012. Using some recent techniques in diagnosis of some zoonotic bacterial diseases transmitted through milk. Alexandria Journal of Veterinary Science, 35: 11-21.

Shamila-Syuhada, A.K., Rusul, G., Wan-Nadiah, W.A. \& Chuah, L.O.2016. Prevalence and antibiotics resistance of Staphylococcus aureus isolates isolated from raw milk obtained from small-scale dairy farms in Penang, Malaysia. Pakistan Veterinary Journal, 36: 98102. 


\section{انتشار المكورات العنقودية الذهبية المعزولة من اللبن الخام ومنتجات الألبان

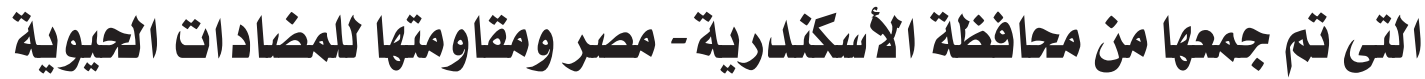

سحر جمال أحمد عبد الحليم(1)، إبراهيه أحمد عبد الحميلد عطية(r)، هشام بيومي الدرع(r)،

أيمن صلاح الصعيدي(๕)

(1) مستشفى الشرطة بالإسكندرية، وزارة الداخلية، الإسكندرية.

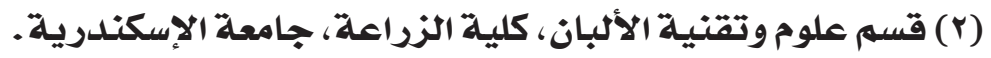

(rr) قسم التغذية، المعهد العالي للصحة العامة، جامعة الإسكندرية.

(§) معمل الوراثة الخلويلة والجزيئية، قسم الوراثة، كلية الزراعة، جامعة الإسكندرية.

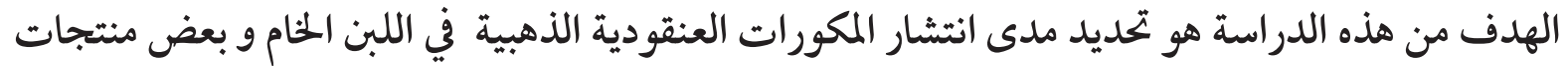

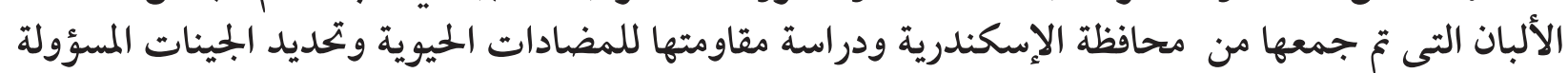

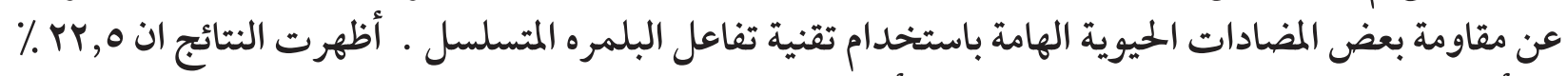

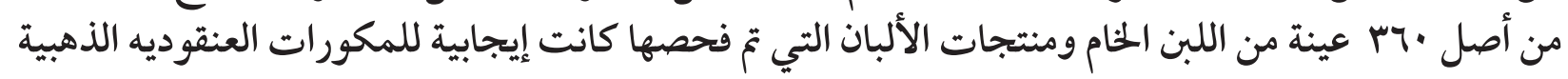

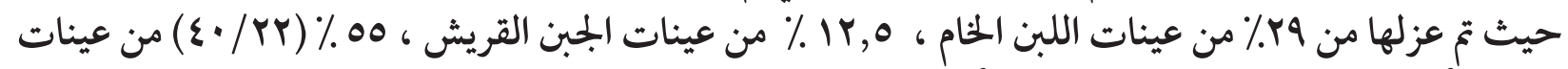

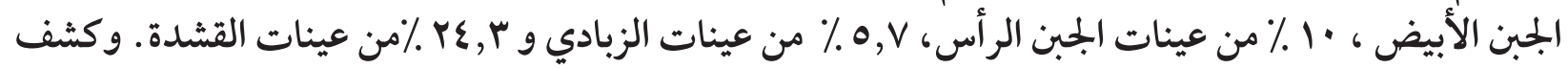

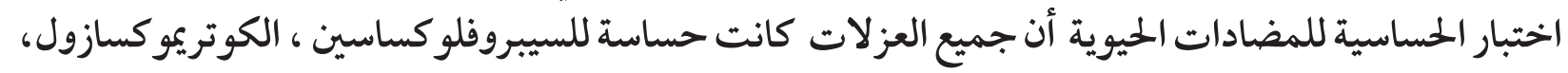

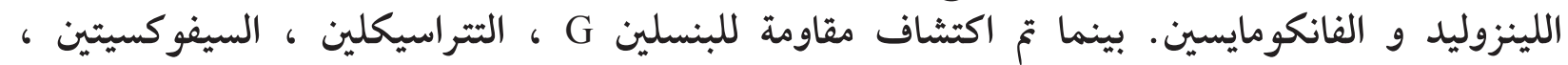

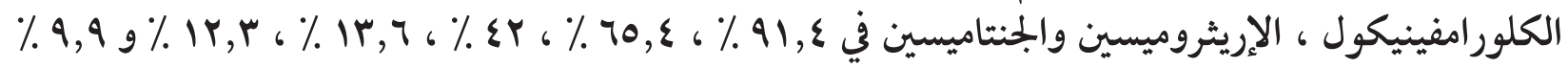

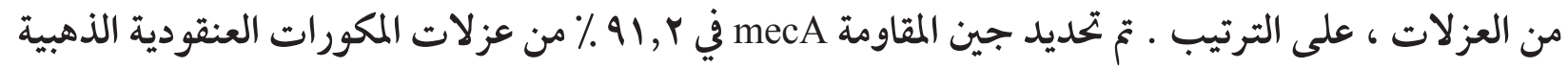

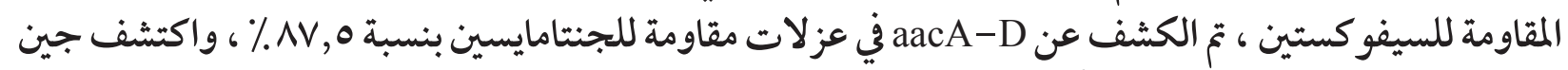
ف في ermC

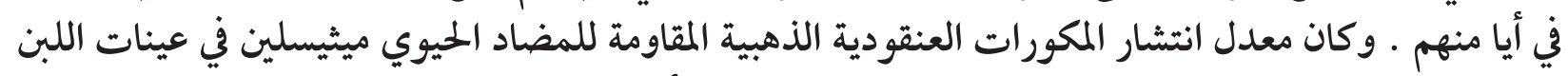

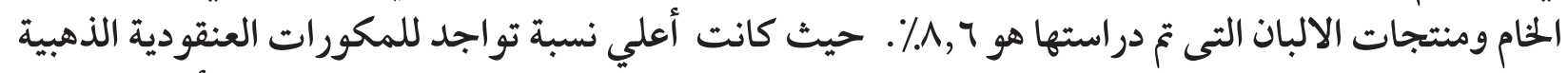

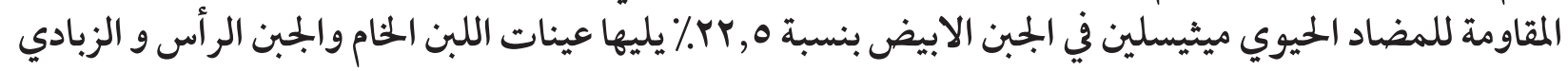

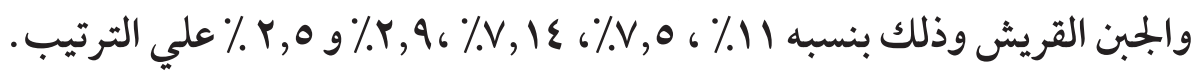


